\title{
Analysis of dithiocarbamate residues in fruits
}

\section{Analiza pozostałości ditiokarbaminianów w owocach}

\author{
Klaudia Pszczolińska*, Justyna Czieszowic
}

\section{Summary}

Dithiocarbamates are fungicidal plant protection products that are often used due to their broad spectrum of activity to protect fruits, vegetables and cereals. Although dithiocarbamate plant protection products have been known for many years, their analysis is still difficult due to their low stability in the plant matrix and low solubility in water and polar solvents. The study presents the characteristics of dithiocarbamates active substances and the methods of determining their residues in fruits. Moreover, the authors described their own research, the subject of which was the validation of the spectrophotometric method for the marking of dithiocarbamate residues in fruit and its application in the analysis of fruit samples as part of the official inspection in 2017-2019.

Key words: dithiocarbamate residues, fruits, marking of dithiocarbamates, spectrophotometry

\section{Streszczenie}

Ditiokarbaminiany to fungicydowe środki ochrony roślin, które są często wykorzystywane ze względu na szerokie spektrum działania do ochrony owoców, warzyw i zbóż. Pomimo, że ditiokarbaminianowe środki ochrony roślin znane są od wielu lat, ich analiza nadal przysparza trudności ze względu na ich małą stabilność w matrycy roślinnej oraz słabą rozpuszczalność w wodzie i rozpuszczalnikach polarnych. W pracy została przedstawiona charakterystyka substancji czynnych należących do grupy ditiokarbaminianów oraz metody oznaczania pozostałości w owocach. Ponadto, opisano badania własne, których przedmiotem była walidacja metody spektrofotometrycznej oznaczania pozostałości sumy fungicydów ditiokarbaminianowych w owocach oraz jej zastosowanie w analizie próbek owoców w ramach urzędowej kontroli w latach 2017-2019.

Słowa kluczowe: pozostałości ditiokarbaminianów, owoce, oznaczanie ditiokarbaminianów, spektrofotometria

\author{
Instytut Ochrony Roślin - Państwowy Instytut Badawczy \\ Oddział Sośnicowice \\ Gliwicka 29, 44-153 Sośnicowice \\ *corresponding author: k.pszczolinska@iorpib.poznan.pl \\ ORCID: 0000-0002-9991-6689
}




\section{Ditiokarbaminiany - charakterystyka i metody oznaczania / Dithiocarbamates - characteristics and determination methods}

Ditiokarbaminiany, które należą do grupy fungicydów mimo wprowadzenia na rynek ponad 70 lat temu nadal są najchętniej stosowanymi fungicydami w Polsce (GUS 2019). Dzięki szerokiemu spektrum działania powszechnie wykorzystywane są w rolnictwie do ochrony warzyw, owoców i zbóż. Poza tym są stosowane przy produkcji papieru oraz $\mathrm{w}$ przemyśle gumowym jako antyoksydanty i przyspieszacze wulkanizacji. Wykorzystywane mogą być również jako środki do konserwacji drewna, substancje do oczyszczania ścieków oraz jako środki przeciwporostowe w systemach chłodzenia wody (Crnogorac i Schwack 2009; Al-Alam i wsp. 2017; Pizzutti i wsp. 2017).

Ze względu na budowę szkieletu węglowego ditiokarbaminiany można podzielić na trzy podklasy: dimetyloditiokarbaminiany (tiuram, ziram), etylenobisditiokarbaminiany (mankozeb, maneb, metiram) i propylenobisditiokarbaminiany (propineb) (Schmidt i wsp. 2013). Zgodnie z definicją podaną przez Komisję Europejską pozostałości ditiokarbaminianów w żywności to całkowite pozostałości wyrażone jako suma disiarczku węgla $\left(\mathrm{CS}_{2}\right)$ powstałe w wyniku zastosowania dowolnego fungicydu ditiokarbaminianowego, w tym manebu, mankozebu, metiramu, propinebu, tiuramu i ziramu (Rozporządzenie WE 2005). Najważniejsze właściwości fizykochemiczne ditiokarbaminianów zestawiono w tabeli 1.

Ditiokarbaminiany charakteryzują się niską toksycznością ostrą, jednak niektóre $\mathrm{z}$ nich mogą powodować problemy zdrowotne, jeśli nastąpi ich kontakt ze skórą, wdy- chanie albo spożycie. Związki, takie jak mankozeb, maneb, ziram czy tiuram mogą powodować dystalną neuropatię obwodową. Ponadto ditiokarbaminiany mogą być przyczyną zakłócenia obwodowego i ośrodkowego układu nerwowego (Al.-Alam i wsp. 2017). Metabolity ditiokarbaminianów, a zwłaszcza etylenotiomocznik, wykazują działanie kancerogenne, mutagenne oraz teratogenne. Poza tym część ditiokarbaminianów wykazuje działanie antybakteryjne w stosunku do bakterii Nitrosomonas i Nitrobacter, co prowadzi do zahamowania procesów nitryfikacyjnych w glebie (RóŻański 1992; Pizzutti i wsp. 2017).

W Polsce dopuszczone do stosowania są 63 środki ochrony roślin (ś.o.r.) zawierające substancje czynne (s.cz.) z grupy ditiokarbaminianów, takie jak ziram, mankozeb oraz metiram (stan na 11.08.2020 r.). Celem poszerzenia spektrum działania, niektóre spośród środków zawierających mankozeb, posiadają drugą s.cz., taką jak: dimetomorf, metalaksyl, famoksat, metalaksyl-M, cymoksanil, walifenalat, benalaksyl-M, amisulbrom, benalaksyl, bentiowalikarb oraz ametoktradyna (https://www.gov.pl/web/rolnictwo/rejestr-srodkow-ochrony-roslin).

Komisja Europejska w roku 2018 nie odnowiła zezwolenia na ś.o.r. zawierające w swym składzie substancję tiuram (Rozporządzenie UE 2018). Wycofane środki stosowano $\mathrm{w}$ ochronie truskawek przed szarą pleśnią (Botrytis cinerea Pers.), jak również w ochronie jabłek przed szarą pleśnią (B. cinerea Pers.) i parchem jabłoni (Venturia inaequalis Cooke/Aderh.), gruszek przed parchem gruszy (Venturia pirina Aderh.), brzoskwiń przed kędzierzawością liści (Taphrina deformans Berk./Tul.) czy wiśni przed gorzką zgnilizną (Glomerella cingulata Spauld. et Schrenk). Komisja Europejska jako przyczynę nieodnowienia ważności

Tabela 1. Właściwości fizykochemiczne ditiokarbaminianów Table 1. Physicochemical properties of dithiocarbamates

\begin{tabular}{l|c|c|c|c|c|c}
\hline $\begin{array}{l}\text { Związek } \\
\text { Compound }\end{array}$ & CAS & $\begin{array}{c}\text { Wzór sumaryczny } \\
\text { Molecular formula }\end{array}$ & $\begin{array}{c}\text { Masa molowa } \\
\text { Molecular mass } \\
{[\mathrm{g} / \mathrm{mol}]}\end{array}$ & $\begin{array}{c}\text { Współczynnik } \\
\text { podziału } \\
\text { oktanol/woda } \\
\text { Octanol/water } \\
\text { partition coefficient } \\
\text { logP }\end{array}$ & $\begin{array}{c}\text { Współczynnik } \\
\text { podziału węgiel } \\
\text { organiczny/woda } \\
\text { Organic carbon/water } \\
\text { coefficient }\end{array}$ & $\begin{array}{c}\text { Rozpuszczalność } \\
\text { w wodzie } \\
\text { Solubility } \\
\text { in water } \\
{\left[\mathrm{mg} / 1,20^{\circ} \mathrm{C}\right]}\end{array}$ \\
\hline $\begin{array}{l}\text { Maneb } \\
\text { Maneb }\end{array}$ & $12427-38-2$ & $\mathrm{C}_{4} \mathrm{H}_{6} \mathrm{MnN}_{2} \mathrm{~S}_{4}$ & 265,30 & $-0,45$ & 2000 & 178 \\
\hline $\begin{array}{l}\text { Mankozeb } \\
\text { Mancozeb }\end{array}$ & $8018-01-7$ & $\mathrm{C}_{8} \mathrm{H}_{12} \mathrm{MnN}_{4} \mathrm{~S}_{8} \mathrm{Zn}$ & 541,1 & 2,3 & 998 & 6,2 \\
\hline $\begin{array}{l}\text { Metiram } \\
\text { Metriam }\end{array}$ & $9006-42-2$ & $\left(\mathrm{C}_{16} \mathrm{H}_{33} \mathrm{~N}_{11} \mathrm{~S}_{16} \mathrm{Zn} 3\right) \mathrm{x}$ & $(1088,6) \mathrm{x}$ & 0,33 & 903012 & 2 \\
\hline $\begin{array}{l}\text { Propineb } \\
\text { Propineb }\end{array}$ & $12071-83-9$ & $\mathrm{C}_{5} \mathrm{H}_{8} \mathrm{~N}_{2} \mathrm{~S}_{4} \mathrm{Zn}$ & 289,80 & $-0,26$ & brak danych \\
\hline $\begin{array}{l}\text { Tiuram } \\
\text { Thiram }\end{array}$ & $137-26-8$ & $\mathrm{C}_{6} \mathrm{H}_{12} \mathrm{~N}_{2} \mathrm{~S}_{4}$ & 240,43 & 1,84 & brak danych & 10 \\
\hline $\begin{array}{l}\text { Ziram } \\
\text { Ziram }\end{array}$ & $137-30-4$ & $\mathrm{C}_{6} \mathrm{H}_{12} \mathrm{~N}_{2} \mathrm{~S}_{4} \mathrm{Zn}$ & 305,84 & 1,65 & no data & 18 \\
\hline
\end{tabular}


pozwolenia podała ryzyko, jakie niesie za sobą stosowanie tiuramu dla konsumentów, pracowników, ssaków, ptaków i organizmów wodnych we wszystkich ocenionych reprezentatywnych zastosowaniach. Ustalony okres stosowania, przechowywania lub unieszkodliwiania ś.o.r. stosowanych nalistnie zawierających tiuram upłynął 30 kwietnia 2019 r. (Rozporządzenie UE 2018).

Opracowane programy ochrony dla producentów owoców zalecają w celu zwalczania chorób grzybowych, ochronę związkami chemicznymi z grupy fungicydów, do których należą ditiokarbaminiany. Według rejestru środków dopuszczonych do obrotu przez Ministra Rolnictwa i Rozwoju Wsi dozwolone do stosowania są środki zawierające mankozeb do ochrony takich owoców, jak jabłka, winogrona, porzeczki i agrest oraz metiram do ochrony jabłoni (stan na dzień 11.08.2020 r.). Jedną z najgroźniejszych chorób przeciwko której wykonywane są zabiegi ditiokarbaminianami w ochronie jabłek jest parch jabłoni ( $V$. inaequalis Cooke/ Aderh.). Ponadto środki znajdują zastosowanie w zapobieganiu takim chorobom, jak mączniak rzekomy winorośli (Plasmopara viticola Berl. et de Toni.), opadzina liści porzeczki (Drepanopeziza ribis Kleb/Holm.), rdza wejmutkowo-porzeczkowa (Cronartium ribicola J.G. Fish), biała plamistość liści porzeczki (Mycosphaerella ribis Kleb.) czy czarna plamistość agrestu (Alternaria grossulariae).

Pomimo, że ditiokarbaminianowe ś.o.r. znane są od wielu lat, ich analiza nadal przysparza wiele trudności, ponieważ są to związki niestabilne w matrycach roślinnych. Ditiokarbaminiany w kontakcie z kwaśnymi sokami roślinnymi ulegają szybkiej degradacji do $\mathrm{CS}_{2}$ i odpowiedniej aminy. Ponadto $\mathrm{z}$ powodu słabej rozpuszczalności w wodzie i innych rozpuszczalnikach polarnych nie można zastosować standardowych procedur oznaczania pozostałości pestycydów (Crnogorac i Schwack 2009). Istotnym problemem jest również możliwość otrzymania wyników fałszywie dodatnich, których przyczyną jest występowanie w niektórych roślinach, np. kapuście, kalafiorze, brokule, sałacie czy grzybach, naturalnych związków siarki, które tak jak ditiokarbaminiany ulegają degradacji do $\mathrm{CS}_{2}$ (Caldas i wsp. 2004).

Jedną z pierwszych i stosowaną do dzisiaj metod oznaczania pozostałości ditiokarbaminianów jest metoda spektrofotometryczna. W zbiorze polskich norm, znajdują się dwie znormalizowane metody oznaczania pozostałości ditiokarbaminianów za pomocą spektrofotometrii. Pierwsza metoda opisuje analizę polegającą na dodaniu do próbki kwasu chlorowodorowego i chlorku cyny (II), a następnie ogrzanie próbki. Podczas ogrzewania uwalniany zostaje $\mathrm{CS}_{2}$ z obecnych w próbce pozostałości ditiokarbaminianów, który jest pochłaniany przez etanolowy roztwór octanu miedzi (II) i dietanoloaminy, tworząc dwa związki kompleksowe N,N-bis(2-hydroksyetylo)-ditiokarbaminiany miedzi (II). Następnie dokonuje się pomiaru absorbancji tego roztworu przy długości fali $435 \mathrm{~nm}$, a otrzymany wynik jest wyra- żony jako suma $\mathrm{CS}_{2}$ (PN-EN 12396-1). Wytyczne zawarte w drugiej normie różnią się tym, że uwolniony $\mathrm{CS}_{2}$ jest absorbowany w metanolowym roztworze wodorotlenku potasu tworząc ksantogenian potasu. Ponadto pomiaru absorbancji dokonuje się przy długości fali 302 nm (PN-EN 12396-3). W obu metodach aparatura do destylacji i pochłaniania jest połączona szeregowo, co powoduje wycieki gazu, trudności w montażu, a także zajmuje znaczną powierzchnię. W celu zmniejszenia wad tego połączenia, w 2001 roku ukazała się publikacja, w której opisano możliwość zastosowania zestawu do destylacji, który złożono w sposób pionowy (Caldas i wsp. 2001). Pomimo wprowadzonego udoskonalenia, metody spektrofotometryczne nadal pozostają czasochłonne, pracochłonne, wymagają użycia dużej ilości próbki i rozpuszczalników oraz mogą generować wyniki fałszywie dodatnie. Jednak ze względu na powszechnie dostępną i tanią aparaturę są to metody nadal powszechnie wykorzystywane w wielu laboratoriach (Matyaszek i wsp. 2017; Ławicki i Hrynko 2018; Nowacka i wsp. 2020).

W związku z niedoskonałościami analizy spektrofotometrycznej opracowano inne metody oznaczania pozostałości ditiokarbaminianów oparte na technikach chromatograficznych. Oznaczanie pozostałości ditiokarbaminianów za pomocą chromatografii gazowej z detektorem wychwytu elektronów (GC-ECD) lub detektorem płomieniowo-fotometrycznym (GC-FPD) opisuje trzecia metoda znormalizowana. Analiza ta polega na ogrzewaniu próbki z kwasem chlorowodorowym i chlorkiem cyny (II) w szczelnie zamkniętej kolbie. Do oznaczeń pobiera się schłodzony gaz znad roztworu (PN-EN 12396-2). Aby ograniczyć ilość zużywanych odczynników, zmniejszyć wielkość próbki oraz przyspieszyć analizę w 2001 roku opracowano zautomatyzowaną metodę chromatografii gazowej (GC-ECD) fazy nadpowierzchniowej (headspace) (Royer i wsp. 2001). Technika ta wyeliminowała czasochłonne etapy procedury i ryzyko błędów związanych z etapem przygotowania próbek do analizy instrumentalnej. Tak jak w przypadku metody spektrofotometrycznej minusem tej metody jest możliwość otrzymywania wyników fałszywie dodatnich. Techniką, która również umożliwia oznaczenie pozostałości ditiokarbaminianów jest chromatografia gazowa sprzężona ze spektrometrią mas (GC-MS). Na etapie ekstrakcji próbka po ogrzewaniu w szklanej butelce $\mathrm{z}$ dodatkiem izooktanu i roztworu chlorku cyny (II) pozostawiana jest do ochłodzenia, a następnie warstwę organiczną poddaje się analizie GC-MS (Cesnik i Gregorcic 2006; Mujawar i wsp. 2014).

Oznaczanie pozostałości ditiokarbaminianów jest także możliwe przy użyciu techniki chromatografii cieczowej. Blasco i wsp. (2004) prowadzili badania, w których do oznaczeń końcowych wykorzystano chromatograf cieczowy $\mathrm{z}$ detektorem mas i jonizację chemiczną pod ciśnieniem atmosferycznym (LC-APCI-MS). Wykonane badania opierały się na wybranych związkach zawierających siarkę, takich jak dazomet, disulfiram i tiuram oraz ich metabolitach 
- etylenotiomoczniku i propylenotiomoczniku. Próbki do badań poddano homogenizacji, a następnie ekstrahowano mieszaniną dichlorometan/metanol i oczyszczano z zastosowaniem rozproszenia matrycy na fazie stałej. Otrzymane wyniki wykazały, że metoda ta nie sprawdziła się dla związków, takich jak tiuram i disulfiram w owocach o dużej zawartości kwasów i dla disulfiramu w orzechach.

W literaturze można także odnaleźć badania z zastosowaniem chromatografii cieczowej z detektorem mas i jonizacją typu elektrosprej (LC-ESI-MS) (Crnogorac i Schwack 2007). Autorzy ekstrahowali próbki owoców i warzyw buforem zawierającym wodorowęglan sodu oraz D,L-penicylaminę. Następnie na etapie oczyszczania ekstraktu zastosowano odpowiednio dobrane filtry strzykawkowe. Na podstawie uzyskanych wyników autorzy stwierdzili, że zaproponowana metoda jest szybka oraz charakteryzuje się wysoką czułością, co umożliwia jednoczesne oznaczenie związków należących do trzech grup ditiokarbamininanów. Podobne badania przeprowadzili Schmidt i wsp. (2013), którzy w swoich badaniach oznaczyli w próbkach owoców i warzyw 6 różnych związków należących do ditiokarbaminianów. Dodatkowo do analizy wykorzystali spektrometrię mas sprzężoną z plazmą wzbudzaną indukcyjnie (ICP-MS). Dzięki temu zostały oznaczone pierwiastki metali, które znajdowały się w związkach ditiokarbaminianowych.

W 2003 roku ukazała się publikacja opisująca wielopozostałościową metodę QuEChERS (Quick, Easy, Cheap, Effective, Rugged and Safe) oznaczania pozostałości ś.o.r. w owocach i warzywach (Anastassiades i wsp. 2003). Metoda jest połączeniem ekstrakcji ciecz-ciecz oraz dyspersyjnej ekstrakcji do fazy stałej (d-SPE). Stanowi szybką, prostą, tanią, efektywną oraz bezpieczną procedurę przygotowania próbek do analizy. Charakteryzuje się również niewielkim zużyciem odczynników, w tym szkodliwych rozpuszczalników organicznych oraz szkła laboratoryjnego, jest więc przyjazna dla środowiska. Od jej opublikowania cieszy się zainteresowaniem wielu badaczy o czym świadczą publikowane modyfikacje metody QuEChERS (Wilkowska i Biziuk 2011; Rejczak i Tuzimski 2015). Metodę QuEChERS cechuje duża elastyczność i możliwość modyfikacji pod kątem badanych związków, rodzajów badanych matryc, wyposażenia i technik analitycznych stosowanych w laboratorium. W związku z tym metoda znalazła zastosowanie w analizie pozostałości w innych matrycach, przykładowo takich jak zboża, miód czy mięso (Rejczak i Tuzimski 2015). Obecnie znajduje zastosowanie w oznaczaniu różnych klas związków chemicznych w różnorodnych matrycach (Bruzzoniti i wsp. 2014).

Metoda QuEChERS została również zmodyfikowana pod kątem analizy pozostałości ditiokarbaminianów. Hayama i Takada (2008), aby ułatwić i przyspieszyć sposób przygotowania próbki, zmodyfikowali metodę QuEChERS celem oznaczenia pozostałości etylenobisditiokarbaminianów w owocach i warzywach. Zastosowana modyfikacja polegała na dodaniu do próbki zamiast $10 \mathrm{ml}$ acetonitrylu, kwasu etyleno-diaminotetraoctowego (EDTA) i siarczanu dimetylu w acetonitrylu, aby nastąpiło przekształcenie ditiokarbaminianów w rozpuszczalne w wodzie sole sodowe. W badaniach jako technikę oznaczeń zastosowano chromatografię cieczową sprzężoną z tandemowym spektrometrem mas (LC-MS/MS). Wykonana walidacja umożliwiła autorom stwierdzenie, że zaproponowana prosta metoda w połączeniu z LC-MS/MS umożliwia wystarczająco czułą, selektywną i precyzyjną analizę pozostałości etylenobisditiokarbaminianów. Z kolei modyfikacja metody QuEChERS zaproponowana przez Kakitani i wsp. (2017) polegała na zastosowaniu wodorowęglanu sodu, zamiast EDTA oraz dodaniu ditiotreitolu jako stabilizatora, aby zapobiec degradacji ditiokarbaminianów. Zmiany te pozwoliły na oznaczenie wszystkich trzech grup związków należących do ditiokarbaminianów w sokach owocowych i piwie. Dla związków propineb, mankozeb, tiuram uzyskano zadowalające wartości odzysków. W zależności od matrycy odzyski wynosiły 92,2-112,6\%. Wszystkie otrzymane wyniki spełniały wymagania stawiane metodzie oznaczania pozostałości w owocach.

Analiza danych literaturowych wskazuje, że nie ma uniwersalnej metody oznaczania pozostałości ditiokarbaminianów, a metody znormalizowane umożliwiają ilościowe oznaczenie całej grupy związków, a nie identyfikację pojedynczych jej przedstawicieli. W związku z tym należy nadal udoskonalać metody i opracowywać nowe, które umożliwiłyby uzyskiwanie wiarygodnych wyników.

\section{Pozostałości ditiokarbaminianów w owocach - walidacja metody i analiza próbek I Dithiocarbamate residues in fruit - method validation and sample analysis}

Spektrofotometryczną metodę oznaczania pozostałości ditiokarbaminianów wykorzystano w badaniach występowania pozostałości ditiokarbaminianów w owocach, które zostały wykonane w ramach urzędowej kontroli pozostałości ś.o.r. w latach 2017-2019.

Pierwszym etapem badań było wykonanie walidacji metody, aby móc sprawdzić czy metoda ta umożliwia otrzymanie wiarygodnych wyników, a co za tym idzie może zostać wykorzystana do oznaczania pozostałości ditiokarbaminianów. Materiał do badań, który był wykorzystywany w procesie walidacji, stanowily próbki takich owoców, jak truskawka, jabłko i winogrono. Analiza wykonanych próbek wykazała, iż były wolne od pozostałości ditiokarbaminianów.

Wykorzystano procedurę opartą na wytycznych znormalizowanej metody PN-EN 12396-1, która polegała na ogrzewaniu próbki $\mathrm{z}$ kwasem chlorowodorowym i chlorkiem cyny (II) $\mathrm{w}$ celu uwolnienia $\mathrm{CS}_{2} \mathrm{z}$ obecnych $\mathrm{w}$ niej pozo- 
stałości ditiokarbaminianów. Uwolniony $\mathrm{CS}_{2}$ był następnie pochłaniany $\mathrm{w}$ etanolowym roztworze octanu miedzi (II) i dietanoloaminy. Absorbancja produktów reakcji mierzona była przy długości fali $\lambda=435 \mathrm{~nm}$. Próbki przed przystąpieniem do analizy fortyfikowane były na 4 poziomach stężeń: (i) $0,025 \mathrm{mg} / \mathrm{kg}$, (ii) $0,25 \mathrm{mg} / \mathrm{kg}$, (iii) $0,75 \mathrm{mg} / \mathrm{kg}$ i (iiii) $1,25 \mathrm{mg} / \mathrm{kg}$.

Walidację metody przeprowadzono w oparciu o wytyczne dokumentu SANTE (SANTE/11813/2017). Parametry walidacyjne, takie jak poprawność wyrażona za pomocą średniego odzysku (70-120\%) i precyzja określana jako wartość współczynnika zmienności $(\mathrm{CV} \leq 20 \%)$ umożliwiły ocenę uzyskanych wyników. Uzyskane średnie wartości odzysków analizowanego związku mieściły się w prawidłowym przedziale $83,5-116,1 \%$, a wartości parametru walidacyjnego, jakim jest CV mieściły się w zakresie od 0,69 do $8,3 \%$ (tab. 2).

Uzyskanie prawidłowych wyników walidacji umożliwiło zastosowanie metody w analizie próbek rzeczywistych. Przedmiotem badań w latach 2017-2019 było 368 próbek owoców pochodzących z produkcji krajowej. Próbki zostały pobrane z terenów takich województw, jak: śląskie, opol- skie, małopolskie, świętokrzyskie, podkarpackie, a ponadto w roku 2019 dolnośląskie, lubelskie i łódzkie. Materiał do badań dostarczony był do Laboratorium Badania Pozostałości Środków Ochrony Roślin w ramach urzędowej kontroli, celem której była weryfikacja prawidłowości stosowania ś.o.r. Oznaczone stężenie sumy ditiokarbaminianów porównano z obowiązującymi najwyższymi dopuszczalnymi poziomami pozostałości (NDP) (Rozporządzenie WE 2005).

Pod kątem występowania pozostałości ditiokarbaminianów przebadano owoce, takie jak: porzeczki, winogrona, truskawki, wiśnie, brzoskwinie, czereśnie, gruszki, jabłka, śliwki, agrest i borówkę amerykańską. W 2017 roku najliczniejszą grupę badanych próbek stanowiły jabłka, śliwki, truskawki i porzeczki, w 2018 roku truskawki i porzeczki, natomiast w 2019 roku winogrona. W roku 2018 przebadano najmniejszą liczbę próbek owoców (85) (tab. 3).

Spośród przebadanych próbek pozostałości dikarbaminianów nie zostały oznaczone w 321 próbkach $(87,2 \%)$, a w 47 przebadanych próbkach (12,8\%) stwierdzono obecność pozostałości poniżej wartości NDP. Próbka borów-

Tabela 2. Uzyskane wartości odzysków fortyfikowanych próbek jabłka, truskawki, winogrona

Table 2. Obtained values of recoveries of fortified samples of apples, strawberries, grapes

\begin{tabular}{|c|c|c|c|}
\hline \multirow{2}{*}{$\begin{array}{c}\text { Poziom fortyfikacji } \\
\text { Fortification level } \\
{[\mathrm{mg} / \mathrm{kg}]}\end{array}$} & \multicolumn{3}{|c|}{$\begin{array}{c}\text { Wartość odzysku - Recovery value } \\
{[\%]}\end{array}$} \\
\hline & jabłko - apple & truskawka - strawberry & winogrono - grape \\
\hline 0,025 & 112,7 & 96,4 & 116,1 \\
\hline 0,25 & 83,5 & 84,9 & 97,0 \\
\hline 0,75 & 92,8 & 89,0 & 94,8 \\
\hline 1,25 & 101,9 & 91,3 & 97,2 \\
\hline
\end{tabular}

Tabela 3. Matryce owoców poddanych analizie w latach 2017-2019

Table 3. Types of fruits analyzed in 2017-2019

\begin{tabular}{|c|c|c|c|c|}
\hline \multirow{2}{*}{$\begin{array}{l}\text { Rodzaj owoców } \\
\text { Types of fruits }\end{array}$} & \multicolumn{4}{|c|}{ Liczba próbek w poszczególnych latach - Number of samples in individual years } \\
\hline & 2017 & 2018 & 2019 & suma - sum \\
\hline Porzeczka - Currant & 19 & 19 & 14 & 52 \\
\hline Winogrono - Grape & 13 & 5 & 48 & 66 \\
\hline Truskawka - Strawberry & 25 & 26 & 18 & 69 \\
\hline Wiśnia - Cherry & 16 & 16 & 3 & 35 \\
\hline Brzoskwinia - Peach & 1 & 1 & 9 & 11 \\
\hline Czereśnia - Cherry & 4 & 0 & 11 & 15 \\
\hline Gruszka - Pear & 13 & 0 & 1 & 14 \\
\hline Jabłko - Apple & 30 & 3 & 3 & 36 \\
\hline Śliwka - Plum & 29 & 15 & 17 & 61 \\
\hline Agrest - Gooseberry & 8 & 0 & 0 & 8 \\
\hline $\begin{array}{l}\text { Borówka amerykańska } \\
\text { Blueberry }\end{array}$ & 1 & 0 & 0 & 1 \\
\hline
\end{tabular}


ki amerykańskiej, wszystkie zbadane partie śliwek oraz czereśni w latach 2017-2019 były wolne od pozostałości ditiokarbaminianów. Stanowiły one odpowiednio 19,0\% i 4,7\% wszystkich próbek bez pozostałości. Najczęściej pozostałości ditiokarbaminianów były oznaczane w próbkach winogron, które stanowiły 40,4\% wszystkich próbek z pozostałościami. Pozostałości oznaczono również w próbkach porzeczek, jabłek, wiśni, truskawek, gruszek, agrestu i brzoskwiń.

Analiza uzyskanych wyników wykazała, iż w żadnej próbce truskawki w 2019 roku nie stwierdzono pozostałości ditiokarbaminianów. Natomiast zarówno w roku 2017 i 2018 w prawie $10 \%$ próbek truskawek oznaczono pozostałości z tej grupy. Wyniki badań truskawek z lat 2017-2019 wykazały, iż rolnicy w 2019 roku zaprzestali stosowania fungicydów zawierających tiuram.

$\mathrm{Na}$ podstawie przeprowadzonych badań można wnioskować, że ś.o.r. zawierające ditiokarbaminiany stosowane są zgodnie z właściwą praktyką rolniczą. Jednak, aby można było wyeliminować potencjalne zagrożenie, jakie może nieść nieprawidłowe stosowanie środków, istnieje potrzeba regularnej kontroli pozostałości ditiokarbaminianów celem potwierdzenia ochrony zdrowia ludzi, zwierząt i środowiska.

\section{Literatura / References}

Al-Alam J., Bom L., Chbani A., Fajloun Z., Millet M. 2017. Analysis of dithiocarbamate fungicides in vegetable matrices using HPLC-UV followed by atomic absorption spectrometry. Journal of Chromatographic Science 55 (4): 429-435. DOI: 10.1093/chromsci/bmw198

Anastassiades M., Lehotay S.J., Stajnbaher D., Schenck F.J. 2003. Fast and easy multi-residue method employing acetonitrile extraction/ partitioning and dispersive soild-phase extraction for the determination of pesticide residues in produce. Journal of AOAC International 86 (2): 412-431. DOI: 10.1093/jaoac/86.2.412

Blasco C., Font G., Pico Y. 2004. Determination of dithiocarbamates and metabolites in plants by liquid chromatography-mass spectrometry. Journal of Chromatography A 1028 (2): 267-276. DOI: 10.1016/j.chroma.2003.12.002

Bruzzoniti M.C., Checchini L., De Carlo R.M., Orlandini S., Rivoira L., Del Bubba M. 2014. QuEChERS sample preparation for the determination of pesticides and other organic residues in environmental matrices: a critical review. Analytical and Bioanalytical Chemistry 406 (17): 4089-4116. DOI: 10.1007/s00216-014-7798-4

Caldas E.D., Conceicao M.H., Miranda M.C.C., de Souza L.C.K.R., Lima J.F. 2001. Determination of dithiocarbamate fungicide residues in food by a spectrophotometric method using a vertical disulfide reaction system. Journal of Agricultural and Food Chemistry 49 (10): 4521-4525. DOI: $10.1021 / \mathrm{jf010124a}$

Caldas E.D., Miranda M.C.C., Conceicao M.H., de Souza L.C.K.R. 2004. Dithiocarbamates residues in Brazilian food and the potential risk for consumers. Food and Chemical Toxicology 42 (11): 1877-1883. DOI: 10.1016/j.fct.2004.07.006

Cesnik H.B., Gregorcic A. 2006. Validation of the method for the determination of dithiocarbamates and thiuram disulphide on apple, lettuce, potato, strawberry and tomato matrix. Acta Chimica Slovenica 53 (1): 100-104.

Crnogorac G., Schwack W. 2007. Determination of dithiocarbamate fungicide residues by liquid chromatography/mass spectrometry and stable isotope dilution assay. Rapid Communications in Mass Spectrometry 21 (24): 4009-4016. DOI: 10.1002/rcm.3312

Crnogorac G., Schwack W. 2009. Residue analysis of dithiocarbamate fungicides. Trends in Analytical Chemistry 28 (1): 40-50. DOI: 10.1016/j.trac.2008.10.008

GUS 2019. Rolnictwo w 2018 r. Główny Urząd Statystyczny, Warszawa, 74 ss.

Hayama T., Takada M. 2008. Simple and rapid method for the determination of ethylenebisdithiocarbamate fungicides in fruits and vegetables using liquid chromatography with tandem mass spectrometry. Analytical and Bioanalytical Chemistry 392 (5): 969-976. DOI: 10.1007/s00216-008-2346-8

Kakitani A., Yoshioka T., Nagatomi Y., Harayama K. 2017. A rapid and sensitive analysis of dithiocarbamate fungicides using modified QuEChERS method and liquid chromatography-tandem mass spectrometry. Journal of Pesticide Science 42 (4): 145-150. DOI: 10.1584/jpestics.D17-025

Ławicki A., Hrynko I. 2018. Pozostałości środków ochrony roślin w pomidorach uprawianych pod osłonami. [Pesticide residues in tomatoes grown under covers]. Progress in Plant Protection 58 (2): 141-147. DOI: 10.14199/ppp-2018-017

Matyaszek A., Szpyrka E., Słowik-Borowiec M., Rupar J. 2017. Pozostałości ditiokarbaminianów w owocach i warzywach pochodzących z Polski południowo-wschodniej oraz ocena ryzyka narażenia zdrowia konsumentów. [Dithiocarbamates residues on fruit and vegetables from the region of south-eastern poland and an assessment of a risk to consumer health]. Bromatologia i Chemia Toksykologiczna 2: $149-155$.

Mujawar S., Utture S.C., Fonseca E., Matarrita J., Banerjee K. 2014. Validation of a GC-MS method for the estimation of dithiocarbamate fungicide residues and safety evaluation of mancozeb in fruits and vegetables. Food Chemistry 150: 175-181. DOI: 10.1016/j. foodchem.2013.10.148

Nowacka A., Hołodyńska-Kulas A., Drożdżyński D., Przewoźniak M., Pszczolińska K., Łozowicka B., Kaczyński P. 2020. Pozostałości środków ochrony roślin w płodach rolnych (2014-2015). [Pesticide residues in agricultrual crops (2014-2015)]. Progress in Plant Protection 60 (2): 81-104. DOI: 10.14199/ppp-2020-010

Pizzutti I.R., de Kok A., da Silva R.C., Rohers G.N. 2017. Comparison between three chromatographic (GC-ECD, GC-PFPD and GC-ITD-MS) methods and a UV-Vis spectrophotometric method for the determinaton of dithiocarbamates in lettuce. Journal of the Brazilian Chemical Society 28 (5): 775-781. DOI: 10.21577/0103-5053.20160227

PN-EN 12396-1. 2002. Żywność o niskiej zawartości tłuszczu - Oznaczanie pozostałości ditiokarbaminianów i disiarczku tiuramu Część 1: Metoda spektrofotometryczna.

PN-EN 12396-2. 2002. Żywność o niskiej zawartości tłuszczu - Oznaczanie pozostałości ditiokarbaminianów i disiarczku tiuramu Część 2: Metoda z wykorzystaniem chromatografii gazowej.

PN-EN 12396-3. 2002. Żywność o niskiej zawartości tłuszczu - Oznaczanie pozostałości ditiokarbaminianów i disiarczku tiuramu Część 3: Metoda ksantogenianowa z wykorzystaniem spektrometrii UV. 
Rejczak T., Tuzimski T. 2015. A review of recent developments and trends in the QuEChERS sample preparation approach. Open Chemistry 13: 980-1010. DOI: 10.1515/chem-2015-0109

Rejestr środków ochrony roślin dopuszczonych do obrotu zezwoleniem Ministra Rolnictwa i Rozwoju Wsi. https://www.gov.pl/web/ rolnictwo/rejestr-srodkow-ochrony-roslin [dostęp: 11.08.2020].

Royer A., Menand M., Grimault A., Communal P.Y. 2001. Development of automated headspace gas chromatography determination of dithiocarbamates in plant matrixes. Journal of Agricultural and Food Chemistry 49 (5): 2152-2158. DOI: 10.1021/jf0013196

Rozporządzenie UE 2018. Rozporządzenie Wykonawcze Komisji (UE) 2018/1500 z dnia 9 października 2018 r. w sprawie nieodnowienia zatwierdzenia substancji czynnej tiuram oraz zakazu używania i sprzedaży nasion zaprawionych środkami ochrony roślin zawierającymi tiuram, zgodnie z rozporządzeniem Parlamentu Europejskiego i Rady (WE) nr 1107/2009 dotyczącym wprowadzania do obrotu środków ochrony roślin, oraz w sprawie zmiany rozporządzenia wykonawczego Komisji (UE) nr 540/2011 (Dz. Urz. L 254, str. 1-3 z 10.10.2018).

Rozporządzenie WE 2005. Rozporządzenie (WE) nr 396/2005 Parlamentu Europejskiego i Rady z dnia 23 lutego 2005 r. w sprawie najwyższych dopuszczalnych poziomów pozostałości pestycydów w żywności i paszy pochodzenia roślinnego i zwierzęcego oraz na ich powierzchni, zmieniające dyrektywę Rady 91/414/EWG (Dz. Urz. L 70, str. 1 z 16.03.2005).

Różański L. 1992. Przemiany pestycydów w organizmach żywych i środowisku. Państwowe Wydawnictwo Rolnicze i Leśne, Warszawa, 275 ss.

SANTE/11813/2017. Guidance document on analytical quality control and method validation procedures for pesticide residues and analysis in food and feed. https://ec.europa.eu/food/sites/food/files/plant/docs/pesticides_mrl_guidelines_wrkdoc_2017-11813.pdf

Schmidt B., Christensen H.B., Petersen A., Sloth J.J., Poulsen M.E. 2013. Method validation and analysis of nine dithiocarbamates in fruits and vegetables by LC-MS/MS. Food Additives \& Contaminants 30 (7): 1287-1298. DOI: 10.1080/19440049.2013.801083

Wilkowska A., Biziuk M. 2011. Determination of pesticide residues in food matrices using the QuEChERS methodology. Food Chemistry 125 (3): 803-812. DOI: 10.1016/j.foodchem.2010.09.094 